\title{
Trajectory of adaptations done by families of children and teenagers with low vision ${ }^{a}$
}

Trajetória de adaptações realizadas por famílias de crianças/adolescentes que apresentam baixa visão Trayectoria de adaptaciones realizadas por familias de niños y adolescentes con baja visión

\author{
Mayara Caroline Barbieri ${ }^{1}$ (C) \\ Gabriela Van Der Zwaan Broekman ${ }^{1}$ (D) \\ Amanda Aparecida Borges ${ }^{1}$ (C) \\ Monika Wernet ${ }^{1}$ (1) \\ Regina Aparecida Garcia de Lima ${ }^{2}$ \\ Giselle Dupas ${ }^{1}$
}

1. Universidade Federal de São Carlos. São Carlos, SP, Brasil

2. Universidade de São Paulo. Escola de Enfermagem de Ribeirão Preto, Ribeirão Preto, SP, Brasil
Corresponding author:

Amanda Aparecida Borges.

E-mail: amandborges@gmail.com.

Submitted on $08 / 14 / 2018$

Accepted on 01/18/2019.

DOI: 10.1590/2177-9465-EAN-2018-0241

\section{Abstract}

Objective: to understand the experience of families of children and adolescents with visual impairment with an emphasis on the adaptations made in daily life. Method: qualitative, research, which used as a theoretical reference the Symbolic Interactionism and analysis of narrative as method. Data collection through a semi-structured interview, recorded with 18 families of children and adolescents with visual impairment, totaling 61 participants from two municipalities in the interior of the state of São Paulo. Results: the analysis of the narratives allowed the understanding of 2 themes: diagnosis: an unexpected and daily process in front of the knowledge of DV. Final considerations: the family makes its own movement of modifications that have been present throughout the trajectory traveled by the members, which are full of interactions and meanings. It is necessary to train health professionals so that they can support the families of children and adolescents with visual impairment with the necessary information and support.

Keywords: Children with disabilities; Low vision; Family nursing.

\section{Resumo}

Objetivo: compreender a experiência de famílias de crianças e adolescentes que apresentam baixa visão, com ênfase nas adaptações decorrentes à condição crônica. Metodologia: pesquisa qualitativa, que utilizou o referencial teórico do Interacionismo Simbólico e como método a análise de narrativa. Coleta de dados por meio de entrevista semiestruturada, gravada com 18 famílias de crianças e adolescentes que apresentavam deficiência visual, totalizando 61 participantes de dois municípios do estado de São Paulo. Resultados: análise das narrativas possibilitou a compreensão de dois temas: Diagnóstico: um processo inesperado e O cotidiano da criança com deficiência visual e sua família. As categorias mostram o processo dinâmico vivenciado pela família ao receber o diagnóstico de condicionalidade da criança. A aceitação é gradual e concomitante às atividades exercidas pelas famílias para buscar qualidade de cuidado à criança. Considerações finais: a família realiza um movimento próprio de modificações presentes em toda trajetória percorrida pelos membros, repleta de interações e significados. Faz-se necessária a capacitação dos profissionais de saúde, para que possam respaldar as famílias de crianças e adolescentes que apresentam deficiência visual com informações e apoio. Nesse sentido, este estudo possibilita aprofundar o conhecimento, e potencializa o aprimoramento da assistência a essas crianças, adolescentes e suas famílias.

Palavras-chave: Crianças com deficiência; Baixa visão; Enfermagem familiar.

\section{Resumen}

Objetivo: comprender la experiencia de familias de niños y adolescentes con deficiencia visual con énfasis en las adaptaciones realizadas en el cotidiano. Método: investigación cualitativa, que utilizó como referencial teórico el Interaccionismo Simbólico y análisis de narrativa como método. La recolección de datos por medio de entrevistas semiestructuradas, grabada con 18 familias de niños y adolescentes con discapacidad visual, totalizando 61 participantes de dos municipios del interior del estado de São Paulo. Resultados: el análisis de las narrativas posibilitó la comprensión de 2 temas: diagnóstico: un proceso inesperado y cotidiano frente al conocimiento de la DV. Consideraciones finales: la familia realiza un movimiento propio de modificaciones que estuvieron presentes en toda la trayectoria recorrida por los miembros, esas repletas de interacciones y significados. Se hace necesario la capacitación de los profesionales de salud para que puedan respaldar a las familias de niños y adolescentes con discapacidad visual con informaciones y apoyo necesario.

Palabras clave: Niños con discapacidad; Baja visión; Enfermería familiar. 


\section{INTRODUCTION}

Visual impairment $(\mathrm{VI})$ comprises the concept of low vision and blindness, being the blind child the one who needs others senses of the human body, besides the vision, to develop her/ himself. Low vision is related to the degrees of intensity, ranging from the simple perception of light to the reduction of acuity or visual field. ${ }^{1}$ It is worth mentioning that both cause repercussions in the life and quotidian of the person with VI and his/her family. ${ }^{2}$

According to data from the World Health Organization (WHO), every 5 seconds one person becomes blind in the world, and around 500 thousand children develop VI every year. In Brazil, 6.5 million Brazilians present some degree of $\mathrm{VI}$, total or partial, affecting all ages. Of these, 150,000 are classified and declared blind. In addition, of the total cases of blindness, $90 \%$ occur in emerging and underdeveloped countries. It is estimated that, by 2020 , the number of people with a visual impairment may double in the world. ${ }^{3}$

The permanent consequences caused by visual impairment give it a chronic character. As a family, living together with a member having a chronic condition is permeated by innumerable feelings and modifications. The family is faced with uncertainties and fear regarding the diagnosis and acceptance of the member in society, as well as experiencing mourning for the loss of the idealized child. ${ }^{1}$ Vision loss is a predisposition for the development of psychic disorders in childhood since it is considered an important sense of communication between the child and the world. ${ }^{4}$

Caring for a child with VI can lead to numerous difficulties and modifications in the routine of family members, such as the lack of information about strategies for care performing, difficulty in accessing health services, overload, lack of support and prejudice. ${ }^{2}$ In this sense, it is necessary to look at the experience of the family in order to understand the difficulties existing to attend the child and the adolescent in chronic condition, and in this article, especially with $\mathrm{VI}$.

Studies aimed to know the interactions established between the social support network and families of children and adolescents with visual impairment, as well as difficulties faced by mothers in the care of these children. They also showed that, despite the potential derived from the relationship with the support network, there are innumerable counterpoints from it. Difficulties were presented, mainly regarding the support of the health services, the misunderstanding about the visual deficiency and the way of care of the child with low vision, the caregiver's overload and the lack of support by the extended family. Thus, the nuclear family self-reinforces itself to provide the necessary care, which commonly becomes impeding in the care of children and adolescents with VI. ${ }^{5,6,7}$

Still, in this same line, another research emphasizes the need for family adaptations, aiming to coexist with the child in a chronic situation, reaching from preparing the family to providing care until the family reorganization. This path involves emotional issues, the relationship between the mother-father couple, readaptations in the social roles of man and woman, and the professional performance of each family member. ${ }^{8}$ In order for children and adolescents with VI to be able to carry out day-to-day activities, several aspects are involved, requiring sensitivity and appreciation of the processes of adaptation to new potential and real demands, by professionals working in care and by the family. ${ }^{9}$ In order to make modifications in the care setting for the person with $\mathrm{VI}$, the family must be instrumented by health professionals through access to information and health services, with a guarantee of qualification for the care of the family member. ${ }^{10}$

There is a need to look at the family's experience regarding child and adolescent care with $\mathrm{VI}$ in order to understand the context experienced by the family in an attempt to deepen knowledge and provide quality and humanized care to these actors. Thus, the object of the study was based on the following question: What is the experience of the family in facing the visual impairment of their children and adolescents?

Faced with repercussions in the daily life of the family that experiences visual impairment, the objective of the research was to understand the experience of families of children and adolescents with low vision, with emphasis on the adaptations due to the chronic condition.

\section{METHOD}

It is a qualitative, descriptive research that considers the universe of the meanings, beliefs and values of the participants. The choice for qualitative research is justified since it allows a deep interpretation of the relationships, behaviors and phenomena, and, thus, provides subsidies so that the provided care is effective and humanized. ${ }^{11}$

In this line of understanding, we use the assumptions of Symbolic Interactionism (SI) as a theoretical reference. This approach has three basic foundations: first, the human being acts in relation to the meaning that things have for him/her; second, the meaning attributed to things is derived from the social interaction that human beings establish between themselves and with the social objects present therein; and, finally, meanings are modified by the interpretive process used by individuals to deal with what they encounter. ${ }^{12}$

This investigation was carried out with family members of children and adolescents that presented VI, as well as the child or adolescent, when they wanted to participate. Data collection was completed in 2015, in two municipalities in the interior of the state of São Paulo.

For the identification of the participants, in municipality A, it was requested the authorization of the Municipal Secretary of Education and the Education Secretary of the state of São Paulo, which provided a list to identify schools that had children and adolescents enrolled with VI to mediate the meeting of the researchers with the family. During the collection of data in municipality $A$, the development of another branch of the project was initiated, in municipality $B$, considering that it would be enriching to contemplate the participation of families of the mentioned municipality, to amplify and densify the apprehended phenomena. Thus, in municipality B, it was contacted an institution specialized 
in the care of people with such disabilities.

In both municipalities, a letter of invitation to participate in the research was used as a strategy for approaching the families, as well as meetings with the main caregiver to address their objectives, resolve doubts and encourage the participation of the largest number of family members in the interview. The concept used for the family is one in which the members themselves define who is part of it. ${ }^{13}$

Participating in the study were 18 families of children and adolescents with VI, totaling 61 participants. In the first moment of the interview, it was used the genogram and ecomap instruments, so that it could characterize the family, know the interactions established among the members and bring us closer to their life history. After the preparation, the semi-structured instrument was applied, which contained guiding questions, such as: 1) Tell me how has been the trajectory of having a child and/or adolescent with VI at home. 2) Tell me how you teach independence activities for this child and/or adolescent.

The questions did not have a rigid sequence, the family who led the interview, and auxiliary questions were included if something was not addressed by family members. The interviews took place in a group, when there was more than one participant, in a single meeting, and were recorded in audio, with an average duration of 120 minutes. These were performed at the domicile (16) and with two families at the specialized institution.

The recruitment and data collection were performed by three researchers, and none of them had previous link with the research participants. At the time of the interview, at least two researchers were present - which facilitated the collection process - especially in the interviews with larger family groups. The recruitment of the participants was ended after reaching the proposed objectives. ${ }^{14}$

As a methodological reference, narrative analysis was used as a strategy to understand lived stories. While narrating, the participant recognizes and elaborates his/her social experience. ${ }^{15}$ In the analysis it was opted for the thematic holistic modality, performing the reading and re-reading of the interview to: establish a central nucleus; pointing out global impressions; specifying the focus of content for the reconstruction of history; and reflective re-reading with specification of representative sections. ${ }^{16}$

In order to identify the narrative clippings, it was used the relationship that the person interviewed presented in relation to the child or adolescent, followed by the sequential number in which the interview was performed and the letter $\mathrm{A}$ or $\mathrm{B}$, to differentiate the municipality in which the family lived. The child or adolescent was identified by index case (IC).

The study was approved by the Research Ethics Committee of the educational institution to which the project was linked, under Opinion No. 1,034,350. The participation of family members was voluntary, with the signing of the Informed Consent Form, and for those under eighteen years of the Term of Assent. All aspects of Resolution No. 466 of 12 December 2012 of the National Health Council were respected. ${ }^{17}$

\section{RESULTS}

Eighteen families of 21 children and adolescents with $\mathrm{VI}$ were interviewed, since three were siblings. The process of data collection and analysis allowed the identification of two big categories: Diagnosis: an unexpected process and The daily life of the visually impaired child and of their family, representative of the experience of families of children and adolescents with visual impairment, with emphasis on the adaptations made in the daily.

The family experiences relate to the child or adolescent to other people, health professionals and the own family. In this context, the adaptations to VI go through a process that begins in the diagnosis and is experienced by the family until the present day.

\section{Diagnosis: an unexpected process}

The diagnosis of $\mathrm{VI}$ comes unexpectedly for some families interviewed, because, upon leaving the maternity hospital, no changes regarding the vision are communicated to them. In this sense, it is the examinations performed at the time of hospital discharge that give the family confirmation of the diagnosis, or the possibility of its existence. Despite this, there are still doubts about the conditionality of the child, which is only perceived in everyday life.

I had already heard that the child that stays in the incubator could have visual problems. But since the doctor said nothing was affected... (Mother 2-A).

In the daily routine of the little child, VI is not always perceptible. The child has behaviors that denote development is occurring within normality, especially in terms of mobility and playing. This hides visual impairment, taking more time for the family to notice the small signs and seek health care. The family does not expect their child to have the diagnosis of $\mathrm{VI}$, making the fact of the chronic condition unexpected from the medical diagnosis, which becomes part of the family. In addition to this unpredictable situation, doubts and questions about child care and the family's ability to offer it adequately emerge.

[...]/ didn't even know he couldn't see. He would do things, he would run, he would climb things, he would change channels, always like that (Sister 2.1-A).

The biggest problem was that we didn't see anything wrong, it was in a few moments that we realized that he did not see. (Mother 6-A) [...] Small things. [...] the curious thing for us is that he walked around the house and did not bump into anything (Father 6-A).

Subsequently, families start becoming aware of small evidences and suggestive signs of $\mathrm{Vl}$, which are confirmed in the search 
for exploration of these. Thus, the diagnosis becomes effective as something unexpected, being in the home environment that the first signs are perceived from the children's behavior. The family begins to look more closely when unusual events begin to manifest, especially linked to the exaggerated approximation to objects. For families with VI historicity, they take back the past and history to use it in the present and confirm identical anormalities presented by the child. When confirming in daily life their suspicions about $\mathrm{VI}$, the family seeks medical attention to confirm it.

We found out by the way he sat watching TV, he was extremely near, it was really so close, that my mother began to notice it (Sister 2.1-A).

$\mathrm{He}$ (IC) lost his sight the same way I did, it's as if the situation that happened to me has come back to the present. I lost... my father threw a lot of candies at me and I said, "Dad, I cannot see!" And I was putting out my hand. And (name of IC 7.2-B) has already started banging his head on the couch, on the wall ... I also gave him a candy (IC), and he said: "Mom, I cannot see!" And I told my husband, "The story is repeating itself just the same!" (Mother 7-B).

The family also observes some unusual signs, such as ocular changes expressed in strabismus and nystagmus, present in some children with VI.

[...] The eye of (name of the IC 4-A) was very crooked (Mother 4-A).

I soon realized that when (name IC 2.1-B) was born, was different, the eye was red and also trembled, had nystagmus, then I scheduled a consultation (Mother 2-B).

\section{The daily life of the visually impaired child and of their family}

Once the diagnosis is established, the family begins to experience the daily life of the child/adolescent with $\mathrm{VI}$ - which at each stage presents challenges and overcoming - and is reorganized from new demands; therapy is present in this process. When the person finds a healthcare that thinks is appropriate, he/she starts to rely on the conducts performed by the medical specialists. The proposals for therapeutic behaviors are decided in the family, with direct influence of the medical team, especially when there is indication of surgical treatment.

The decision-making process is often the responsibility of parents and guardians, who assume the responsibility and the consequences of such a choice for visual ability and consequently the reflections on the development and living conditions of the VI member. This phase of therapeutic choice may occur in adolescence, and it is up to the young person with $\mathrm{VI}$ to share responsibility and decide on the course of action to be taken.
Feelings of fear, doubt and hope are part of this experience. The greatest fear is that the child, in carrying out the procedure, will lose the little vision he/she has. Parents also suffer at this stage because they feel very responsible for the child's future.

[...] I had to make the decision: either he did the surgeries, or he would become blind (of one eye), how he ended up becoming. [...] I had to try [...]. It was very difficult and it is difficult until today. As now, this decision of taking out his eye, this for me is being very difficult to think, because I do not know how it will be [...]; the doctor told him that this decision is his, that he will have to take, because to see will be no longer with that eye [...] (Mother 8-A).

The doctor said, "I'll explain: if we do not have surgery, she will lose her vision, and if we try to take everything that is broken and work with glasses, there is a great possibility of her having little vision, but seeing!" And I said: "You give me five minutes that I'm going to smoke and l'll be right back?" The children behind me and I cried, rolled the hair and cried. I came back and said, "Doctor, I think you can do this surgery!" And I cried ... I sat in that hospital, and I cried (Mother 5-B).

Once the therapeutic resource - glasses, magnifying glass, walking stick - is inserted into the daily life of the child/adolescent, there is a certain strangeness, until, over time, the use becomes habit. Despite the benefits that made the family choose one of them, it is not easy to understand how much the resource evidences the deficiency, which generates suffering by the confrontation established with what is socially considered normal.

Thus, adaptation is also a demand of the family, which requires a period of experience so that, as the child or adolescent, becomes familiar with the instrument of support. The family creates adaptive processes to deal with the new situation of the child presenting VI. The management and administration of children's daily lives bring expectations regarding the treatment resource and the benefits related to it.

In this context, as adaptive forms to the chronic condition, the family maintains vigilance regarding the use of optical resources; is attentive and, at times when the child or adolescent does not use them, the demanding comes from this process, aiming to make the child responsible for self-care. Such actions are performed so that they do not submit the vision to extreme efforts. In this process, the family may face heterogeneity in accepting the resource despite efforts, with some who accept very well and others not so much.

The family remains attentive and hopeful in showing signs of success. The family is euphoric and very pleased to observe the changes the child has undergone and changes in behavior, becoming more active, curious, with better acquisitions in the development and performance of the Daily Life Activities (DLAs). Conquests and independence are correlated to the good adap- 
tation of daily life to treatment resources.

When he started wearing his glasses, it was all new (Father 6-A). [...] He did the surgery, began to wear the glasses: another child. He seems to want to run more, to move more, to mess up more [...] (Mother 6-A).

[...]. As we were in many in the family, we were always seeing if he would take them off, we would not give him a minute without his glasses. So he practically did not stay without his glasses. We all gave the support and he got accustomed (Mother 2-A).

Treatment resource incorporates the child's identity by being characterized as a need, broadens their horizons of life, and they begin to use it to perform all the Daily Life Activities (DLAs). The glasses are incorporated to the person, not as a separate prop, but composing their "identity", to the point of being forgotten, of being withdrawn.

[...] the glasses are everything for him, [...]. He does not go without them [...]. Takes a shower with them (Mother 6-A) [...]. Just take them off at bedtime, if I do not sleep with my glasses! (IC 6-A).

[...] he likes to wear his glasses! [...] (Mother 1-B). If I take his glasses off, he looks strange, I barely even recognize him! (Cousin 1-B). Yeah, he says it's a part of him, you know? He already understands as if it were part of him (Mother 1-B).

Among the necessary adaptations for the family, is the acceptance of the condition of having a member with VI. Concomitant with the initial impact of the diagnosis and the decisions made in the therapeutic process, the family seeks, in accepting the condition, possibilities to make the trajectory simpler and milder. Family adaptation to diagnosis is difficult at the beginning when the VI member experiences prejudiced situations or when low vision (LV) progresses with worsening. Autonomy is a family objective, which is reorganized and fostered through emotional, instrumental and informational support and other practical interventions aimed at success in everyday activities.

It was difficult for me to know that he lost more of his vision... he lost everything with one eye and sees little of the other ... Leave him here (home) alone and go to work. [...] but then I started to teach him everything, now he looks great, thank God. From the little vision he has, he gets by very well (Mother 8-A).

[...] you have to have a lot of will power, accept the other and fight. [...], love is the basis of everything, when you have love, you do things. Leave the other things, the other differences (Mother 7-B). [...] It is not easy for anyone, but if you fight and go after it, you can treat your child (with VI) like any other, it has no difference, he will live in the same world with the same difficulties (Father 7 -B).

In addition to the acceptance of the diagnosis, the family members reinforce the importance of respecting the form and the time demanded in the execution of the tasks of the day to day. They also mention the offer of opportunities to acquire new learning and the need to invest time in teaching.

[...] the institution had a history of taking them by van and bringing... when I stopped working I took the bus with them, would be showing the way [...]. The other day once again, I did it almost a year, every day [...] today they come back from school alone [...] (Mother 7-B).

With the acceptance of the diagnosis, the family members glimpses possibilities for the $\mathrm{VI}$ and believe that this diagnosis does not have great repercussions for the family as well as the individuals. They even go as far as forgetting the diagnosis. For this reason, the adjustments inserted in the daily life, by the family, are minimal. Such actions are justified because they believe that the disabled member does not present great difficulties, and the vision that he/she still has collaborates for the development of actions, especially those carried out at home.

I had no difficulty (IC 6-A). [...]. So he does the normal things that all children do, he goes to the movies, he plays... whatever a normal child does, he does. He uses the computer like nobody else; he does everything like a normal child; so I treat him like a normal child. For me it has no difference, it is normal (Mother 6-A).

The biggest difficulties I had with the IC was not at home, it was where we were going because at home he was always very active... honestly, there were times I even forgot that he had a problem (Mother 3-B).

The adaptations, when carried out by the family, are associated with facilitating visualization and mobility for the child. With regard to clothing, the family looks for printed clothing and, when necessary, helps in the choice of clothing. In relation to the furniture of the house, the family keeps the objects in the same place to avoid accidents. For reading of some children and adolescents with $\mathrm{VI}$, it is necessary the amplification, being the relatives, often, those responsible for adapting such materials. The experience of adaptation is built daily in the quotidian interaction of children and adolescents with LV and their families.

His sister is who does the laundry... because he does not have a uniform at school (Mother 5-A). [...] lask her where 
is the front and where it is behind, because I cannot see (IC 5.2-A); [...] underwear, clothes ... the shirt he knows by drawing... (Mother 5); shoe, when it is to tie, there I put it and she ties, I'm who puts the stocking. [...] if itunties (lace) at school I put inside the shoe (IC 5.2-A).

I take everything out of the way, I leave it free, without many furniture. There isn't a lot of sofa, rug, it is always free (Mother 10-B). No obstacle in the middle (Father $10-\mathrm{B}$ ), because it often happens of her to stumble (Mother 10-B).

[...] depending on the size I type. If not, l'll get a copy machine and enlarge, or else l'll go to a printer and ask to put it on A3 paper, which is very large (Mother 7-B). The booklet that has many pages, we take and ask for it like that (Father 7-B). Drawing, when they were small, we also expanded, we always had this care with them (Mother 7-B).

Difficulties are experienced in the process of experiencing adaptations when the family cannot know exactly how the individual with $\mathrm{VI}$ is seeing, especially when the child is younger. The family feels the desire to be able to quantify the VI, but fears that the questioning on such subjects can intimidate the children and adolescents. Thus, as a form of stigma, the family exempts the existence of $\mathrm{VI}$, believing that this contributes to the child and adolescent in coping with the situation. Doubt about the degree of VI may decrease as the child grows, as he verbalizes more clearly what and how much he can see.

[...] I did not know if I had to ask if he was seeing, if I shouldn't ask him so that I wouldn't embarrass him. So I just stayed on my own (Sister 1.3-A).

But until now we do not know how he sees, because he does not know how to talk about it yet. [...] I also do not know if it is so clear or if it is still blurry... Because before he saw everything blurred (Mother 2-A).

Itell (name of IC 4-A) that he has to know if he is better or not. When he was small it was difficult, I had to realize... but now he can tell if he is seeing better, worse, if he is in pain. He is already at an age that I no longer need to be talking [...]. It is he who has to see and tell the doctor what he is feeling, the truth (Mother 4-A).

Recreation activities, which normally families guide to be made in the outside area of the house, for children with VI them happening inside is accepted with tranquility by the family since the home environment is the easiest place for supervision and where the child feels safer.
[...] he plays more in the house... even by bicycle he rides here in the hall (Mother 5-A); it is because he is afraid to ride out there, when he wants to ride out there either he calls me or he calls his mother because he is afraid to ride alone (Sister 5-A).

[...] I avoided going out into the street, I always kept her in the house, and when she went to play I was always more attentive [...] (Mother 1-B).

Actions developed by the family seek to protect their children from risk situations. Thus, ways of conceiving the stimuli are created, but always being vigilant. Such actions can lead to independence limited to the home space. What children and adolescents with $\mathrm{VI}$ perform outside the home is restricted to actions they have performed for years, without greatly expanding the repertoire.

Here near the house he goes... there to the dentist it is difficult because it's an intersection of four streets, it is difficult even for those who have good vision... even more for him who has this difficulty [...], I am worried, then it's easier to leave him at the door than to be worried... but I do not limit him! [...], so these are the limitations that he has... more on the street, because in the house, close to home, here in the back street where he goes to play with the boys, is quiet (Mother 4-B).

Adaptation is necessary because of the decreased vision of children and adolescents, as well as the risks related to eye health and accidents that some activities may cause. The protection is not rigid, it presents nuances, everything the family does, aiming for protection, is to try to keep the child and the teenager with VI from predictable risks.

[...] she (IC 5.1-A) has the retina thin, looks like a hair, she cannot play ball, ride a bike, jump rope, these things (Mother 5-A). These jumping games like that.... she can't ... if she falls and hits her head, she's blinded immediately (Sister 5-A).

He wanted a bike, he liked it, but it's not a question of liking it, it's a matter that he cannot so he won't harm himself [...]. In a moment it is going to happen something worse, no one is seeing that he has problem, goes on him and done! The danger was there (busy place) for him to pass (Mother 4-A).... Then I got discouraged (from the bike), I started liking songs, these things, today any song you give me to play I play, any song... I stay at home playing [...] (IC 4-A).

The expectations of families of children and adolescents with 
$\mathrm{VI}$ are surrounded by doubt and fear related to the progression of the problem. The main caregivers also question who will play the role of caregiver in the future, in their absence. The family, when thinking about all the possibilities for the future, constantly seeks the learning as a way to instrumentalize the children.

If he becomes without sight it will be even harder for me. [...] I ask God that he never lose his vision; he no longer sees well, if he loses vision, my God, I do not even know what I do in life (Grandmother 3-A).

[...] I want them to learn more, go deep, I want them to learn to play on the computer [...] I want the best for them, I want them to study [...] a teacher of them said:Mother, put them in the Braille, [...]" I think they have to have these lessons, [...] / cannot leave them left around... as the saying goes: "Mother is not for all life!" (Mother 5-A).

\section{DISCUSSION}

Receiving the diagnosis of $\mathrm{VI}$ disrupts family dynamics, which has to be reorganized to meet the health needs of the child or adolescent, since diagnosis is a noteworthy and significant event in the family experience, characterized by a nebulous and unexpected path, and which requires daily adaptations. Authors claim that most diagnoses related to disability occur late..$^{18}$

The challenges that the $\mathrm{VI}$ diagnosis presents are still many. Authors mention that eye health care is abandoned and, in order to make changes in this scenario, it is necessary to invest in actions that ensure early diagnosis and treatment, that there is continuity of long-term assistance..$^{19}$ Studies point out that public health programs related to ophthalmology are more directed to school and elderly health, and it is necessary to expand to the younger children and to improve and supervise existing strategies, such as the Red Reflex Test in newborns. ${ }^{20}$

Parents reveal feelings of denial, sadness, revolt, confusion, and guilt upon being notified of their child's disability. Thus, it is essential that professionals are prepared to handle such a situation. Parents state that there is a lack of preparation of the family to receive the information of the disability and also of the professionals - specifically the doctor - to report the diagnosis. ${ }^{20}$ Information, when properly provided by health professionals, becomes a differential in the perception of the family concerning $\mathrm{VI}$. Often, the lack of knowledge about the pathology, the lack of access to care and the lack of information can generate feelings of fear about care. ${ }^{21}$

The family feels incapable and without confidence, seeks to rebuild their own identity, adapt and reorganize themselves to face the experience of living through the disability in the home environment. ${ }^{21}$ Research done with children with disabilities found that initially parents expressed feelings of anger, frustration and fear, but they felt the need to face the situation in a positive way and control the emotions so that they could help their children. ${ }^{9}$ The event of the diagnosis of the deficiency can still be ambiguous for the parents when they recognize in it a possibility of hope for the treatment and recovery. ${ }^{2}$

From the view of Symbolic Interactionism, the experience of this situation goes through several stages of acceptance and adaptation. The overcoming of each phase occurs from the process of interpretation and recognition of the new situation, which leads to the development of the human response of confrontation and adaptations. ${ }^{12}$

From the diagnosis, the possibilities of treatment appear. As for the most used strategies among children and adolescents with VI of this investigation, were optical resources, such as glasses. Adapting to them involves the child, but it is also a family demand, since the family needs to supervise their use until the members with VI have incorporated them into the daily life. Among the available treatment resources, optical resources (magnifying glasses, glasses) are widely used in people with low vision, since these instruments are essential to improve the use of residual vision, acting directly in the best performance of daily activities, autonomy and life quality of these people..22 The family seeks that individuals and the child or adolescent visualize themselves in their normality, revealing to them that it is possible to live with the limitations of $\mathrm{VI} .{ }^{12}$

After acceptance, the family reorganizes its daily life, performs behavioral, structural and organizational modifications, in order to enable the development of the member with VI. The involvement of the family is essential for the acquisition of autonomy and independence of the person presenting VI. ${ }^{23}$ Providing a space for family interaction in which people who have $\mathrm{VI}$ are respected in their particularities is essential for the development of potentialities. Unfortunately, the family structure can be organized in such a way that the child has little time for the execution of skills, causing the family members to anticipate or accelerate the accomplishment of daily tasks. ${ }^{4}$

In addition to the modifications in the family posture, adapting the home environment is an opportunist way of having decent development. In this process of adaptation, the family may present difficulties due to the lack of knowledge of the demands that $\mathrm{VI}$ generates and the lack of support. ${ }^{21}$ The professional nurse must be able to work with families that experience disability, strengthening these members so that they can consistently perform care. ${ }^{24}$

In spite of all the work carried out by the families of this research, it is evident, as difficulties of people with VI, mobility on the street and access to public transportation. Corroborating with the findings of this study, a survey revealed that among the mobility difficulties reported by adolescents with VI, the biggest complaint was related to using the bus. Among the strategies used to overcome this difficulty, were mentioned the signaling for all buses to stop and communication with other people when they asked the number of the approaching bus. Authors further emphasize that although people with VI use these strategies, it is expected that bus companies will insert larger and more contrasting signs. ${ }^{10}$

The greatest difficulties faced by people who are in this condition are outside the home. Authors assert that society views in disability a difference associated with disadvantage and cons- 
traints and, thus, they are treated as incapable and fragile. ${ }^{24}$ In this sense, children and adolescents with $\mathrm{VI}$ are often isolated, having restricted opportunities to interact with other people besides their family.

Society marks people with disabilities as those who are incapable and powerless. Stigma leads people with disabilities to be considered incapable of autonomy. This fact is made explicit in the usual solitude and isolation experienced by them, derived from the restricted social relationship or inefficient support networks. ${ }^{24}$

Among the adaptations made by people with $\mathrm{VI}$, verbal communication is a strategy widely used to deal with obstacles imposed by low vision. The word is the main form of interaction established by people with $\mathrm{VI}^{9}$. The word integrates people into society, making them active rather than passive to the stimuli received.Thus, children and adolescents with VI, when presenting difficulties in some moments of interaction, are not limited, but seek, through words, interaction with other people.

In the family trajectory, the supervision action, in addition to being carried out with the intention of protecting its members with VI, can often be performed due to fear and insecurity, for not knowing the best strategy to perform care for this child. Research carried out with families of children with congenital anomaly observed that overprotection was performed by associating the child as fragile and in need of continuous supervision ${ }^{9}$. Actions of overprotection and infantilizing of the member with VI have repercussions on family life; the caregivers perceive that such attitudes generate a decrease in the possibilities of learning, which affects the increase of dependence. ${ }^{12}$ They may also present increased insecurity, accommodation and reduced interest in carrying out daily activities. This can be justified by the fact that it is in the social interaction that the human being defines and acts in the face of the situation experienced, according to the meanings constructed in this relation. ${ }^{12}$ In order for the attitudes of overprotection to not happen, the family must be oriented and supported by professionals so that they can actually be part of the rehabilitation of its members. ${ }^{10}$

A study that corroborates our findings showed that mothers of children with VI presented concern and fear of their children getting hurt in day to day activities. Such feelings generate a relation of overprotection with permanence in the home, believing to be a protected environment due to the possibility of observing the children full time. ${ }^{23}$ Thus, the family reflects on and questions the threshold between protecting and overprotecting. This reflexive process is explained by $S I$ based on the concept of social interaction, which states that all symbolic interaction is surrounded by reflection, interpretation and action. ${ }^{12}$ From the interaction established between the members with VI, the family can reflect on their behavior and modify them.

Although it is not possible to establish clearly the level of low vision that the child or adolescent presents, it is a fact that the $\mathrm{VI}$ has a direct influence on the experience of the families. But, even with the difficulties experienced by the family, in the face of $\mathrm{VI}$, it reestablishes itself, adapts itself to the way of being family and finds the balance to face the condition.

In this sense, it is necessary the performance of health professionals, especially nurses, towards the families of children with $\mathrm{VI}$, so that the necessary guidelines on the care and importance of child stimulation, communication and interaction take place. Thus, the family can adapt and live safely in relation to the performance of care. ${ }^{6}$ It is essential to understand the need for the development of children and adolescents with disabilities and their families in different health care providing systems. Professional support can reorganize and empower family members to care for the VI member by recognizing the real possibilities for action and thus offering effective opportunities for healthy development. ${ }^{10}$ Authors further emphasize the need for training of health and education professionals in face of the specificities of each disability. ${ }^{25}$

\section{FINAL CONSIDERATIONS}

The study aimed to understand the experience of families of children and adolescents with visual impairment, with emphasis on modifications and adaptations made in daily life. The families reported in the narratives the trajectory traversed, being this dynamic full of interactions and meanings that Symbolic Interactionism helped us in understanding.

The modifications begin with the perception of the first signs of $\mathrm{VI}$, with confirmation of the diagnosis, and also from the conducts to be taken for the therapeutic process. The introduction of resources is a milestone in the families' lives, which point out the change in behavior and in the improvement of the performance of the DLAs by the members with VI.

The process of family adaptation becomes more difficult at the beginning of the trajectory. Over time, the family finds the strength to face the situation and seeks in teaching, independence, adaptation strategies and respect for the peculiarities of people with VI, sources to improve daily life and look optimistically at disability. Although the family provides the independence of children and adolescents with $\mathrm{VI}$, it sometimes performs protective actions and questions about the threshold of overprotection. We emphasize here the essential role of health professionals and especially nurses - in relation to families, so that they provide space for interaction, dialogue, reflection, as well as information that empowers them to care for their members, based on the possibilities that exist in the face of visual disability and not on the limitations.

Health professionals should play the role of collaborators in the confronting of $\mathrm{VI}$, instrumentalizing the family with the necessary information and clarification about the stimulation and adaptations in the home environment, in addition to establishing a trust relationship so that they can support families in the modifications generated by VI. The translation of knowledge and its implementation process by nurses and health services are important, in the sense of empowering families to care for the chronic situation.

One of the limitations of this study is the fact that we do not deepen in the role of the health professional. We also do not relate 
the adaptation that the family made to the stage it experiences, as well as to its family structure or to its life context, which are factors that influence the adaptation of the family system. Similarly we do not take into account the age of the child or adolescent. Such facts can bring reflections on ways of improving and orienting families that have the diagnosis of $\mathrm{VI}$ in children and adolescents.

One of the major concerns cited by families is related to the fact of the individual's social reintegration. This is a situation that needs to be explored in order to help families in the care outside of home.

In spite of the existing limitations, this research contributes to add to the literature the experience of the family towards the necessary adaptations to the child and the adolescent with $\mathrm{VI}$, since the existent researches are related to the network of support of the family, as well as to the specific care to these individuals.

\section{FINIANCIAL SUPPORT}

Scholarship granted by Fundação de Amparo à Pesquisa do Estado de São Paulo - FAPESP, from December 1, 2014 to February 29, 2016, to Mayara Caroline Barbieri.

\section{REFERENCES}

1. Ministério da Saúde (BR). Presidência da República. Secretaria Especia dos Direitos Humanos. Coordenadoria Nacional para Integração da Pessoa Portadora de Deficiência. Acessibilidade. Brasília (DF): Secretaria Especial dos Direitos Humanos; 2008. 264 p. Available from: http://www.crfsp.org.br/phocadownload/acessibilidade-compilado_de_ legislacoes.pdf

2. Hamurcu M, Kara K, Congologlu MA, Hamurcu U, Almbaidheen M, Turan A, et al. Relationship between perceived parenting style with anxiety levels and loneliness in visually impaired children and adolescents. Arch Clin Psychiatry (São Paulo) [Internet]. 2016 Sep/Oct; [cited 2017 Dec 11]; 4(5):112-5. Available from: http://www.scielo.br/scielo. php?script=sci_arttext\&pid=S0101-60832016000500112\&lng=en. DOI: http://dx.doi.org/10.1590/0101-60830000000096

3. World Health Organization (WHO). Visual impairment and blindness; 2010 [Internet]. [cited 2015 May 24]. Available from: http://www.who. int/mediacentre/factsheets/fs282/en/

4. Silva FHOB, Cavalcante LIC. Family routines for children with special needs in adoptive families. Psic Teor Pesq (Brasília) [Internet]. 2015 Apr/Jun; [cited 2018 Apr 11]; 31(2):173-80. Available from: http://www. scielo.br/pdf/ptp/v31n2/0102-3772-ptp-31-02-0173.pdf

5. Barbieri MC, Broekman GVDZ, Souza ROD, Lima RAG, Wernet M, Dupas G. Rede de suporte da família da criança e adolescente com deficiência visual: potencialidades e fragilidades. Ciênc Saúde Coletiva [Internet]. 2016 Oct:21(10):3213-23. Available from: http://www.scielo. br/scielo.php?script=sci_arttext\&pid=S1413-81232016001003213

6. Pintanel AC, Gomes GC, Xavier DM. Mothers of visually impaired children: difficult and easy aspects faced in care. Rev Gaúcha Enferm [Internet]. 2013 Jun; [cited 2018 Oct 26]; 34(2):86-92. Available from: http://www.scielo.br/scielo.php?script=sci_arttext\&pid=S198314472013000200011\&lng=pt. DOI: http://dx.doi.org/10.1590/S198314472013000200011

7. Hamurcu M, Kara K, Congologlu MA, Hamurcu U, Almbaidheen M, Turan A, et al. Relationship between perceived parenting style with anxiety levels and loneliness in visually impaired children and adolescents. Arch Clin Psychiatry (São Paulo) [Internet]. 2016 Sep/Oct;43(5):112-5. Available from: http://www.scielo.br/scielo.php?script=sci_arttext\&pid $=$ S0101-60832016000500112
8. Gomes GC, Mota MS, Moreira MAJ, Jung BC, Xavier DM, Silva CD (Des) preparation of family member for the care of children with chronic illness. Rev Enferm UFPI [Internet]. 2017 Jan/Mar;4(1):47-53. Available from: http://www.ojs.ufpi.br/index.php/reufpi/article/view/5737

9. Silva MR, Airoldi MJ. A influência do familiar na aquisição de habilidade funcionais da criança com deficiência visual. Rev Ter Ocup Univ (São Paulo) [Internet]. 2014 ;25(1):36-42. Available from: http://www.revistas. usp.br/rto/article/view/62504

10. Santos JP, Maranhão DG. Nursing care and pain management in hospitalized children: literature review. Rev Soc Bras Enferm Ped [Internet]. 2016 Jun; [cited 2018 Apr 2011]; 16(1):44-50. Available from: https://sobep.org.br/revista/images/stories/pdf-revista/vol16-n1/ vol_16_n_1-artigo-de-revisao-2.pdf

11. Morse JM. Introducing the first Global Congress for Qualitative Health Research: What are we? What will we do--and why? Qual Health Res [Internet]. 2012 Feb;22(2):147-56. Available from: https://www.ncbi.nlm. nih.gov/pubmed/21934031

12. Charon JM. Symbolic interactionism: an introduction an interpretation, an integration. 10th ed. New Jersey: Prentice Hall; 2010.

13. Wright LM, Leahey M. Enfermeira e famílias: guia para avaliação e intervenção na família. 5a ed. São Paulo: Roca; 2012.

14. Ribeiro J, Souza FN, Lobão C. Saturação da Análise na Investigação Qualitativa: Quando Parar de Recolher Dados? Rev Pesq Qualit (São Paulo) [Internet]. 2018 Apr;6(10):iii-vii. Available from: https://www. researchgate.net/publication/324694328_EDITORIAL_Saturacao_da Analise_na_Investigacao_Qualitativa_Quando_Parar_de_Recolher_ Dados

15. Castellanos MEP. A narrativa nas pesquisas qualitativas em saúde. Ciênc Saúde Coletiva [Internet]. 2014 Apr; [cited 2015 Apr 20]; 19(4):1065-76. Available from: http://www.scielosp.org/scielo.php?script=sci_arttext\& pid $=$ S1413-81232014000401065

16. Lieblich A, Tuval-Mashiach R, Zilber T. Narrative research: reading, analysis and interpretation. Newbury Park: Sage; 1998.

17. Ministério da Saúde (BR). Diretrizes e normas regulamentadoras de pesquisa envolvendo seres humanos. Resolução № 466, de 12 de dezembro de 2012. Conselho Nacional de Saúde. Brasília (DF) Ministério da Saúde; 2012. Available from: http://bvsms.saude.gov.br/ bvs/saudelegis/cns/2013/res0466_12_12_2012.html

18. Almeida TS, Araújo FV. Diferenças experienciais entre pessoas com cegueira congênita e adquirida: uma breve apreciação. Rev Interfaces [Internet]. 2013 Jun; [cited 2018 Fev 20]; 1(3):1-21. Available from: http:// interfaces.leaosampaio.edu.br/index.php/revista-interfaces/article/ view/24/29

19. Valverde CNL, Nacif TCB, Freitas HO, Queiroga TM, Bomfim-Pereira MG. Detecção da prevalência de baixa visual e tratamento no grupo etário 4 a 7 anos. Rev Bras Oftalmol [Internet]. 2016 Jul/Aug; [cited 2017 Dec 11]; 75(4):286-9. Available from: http://www.scielo.br/scielo. php?script=sci_arttext\&pid=S0034-72802016000400286\&lng=en. DOI http://dx.doi.org/10.5935/0034-7280.20160057

20. Nascimento GCC, Gagliardo HGRG. Atenção à saúde ocular de crianças com alterações no desenvolvimento em serviços de intervenção precoce: barreiras e facilitadores. Rev Bras Oftalmo [Internet]. 2016 Oct; [cited 2017 Dec 11]; 75(5):370-5. Available from: http://www.scielo.br/scielo.php?script=sci arttext\&pid=S003472802016000500370\&lng=en. DOI: http://dx.doi.org/10.5935/00347280.20160074

21. Cruz TH, Tatsch PN, Piccin C, Machado LG, Chaves OCS, GirardonPerlini NMO. Dificuldades enfrentadas por cuidadores familiares de pacientes acometidos por acidente vascular encefálico. Rev Rede Cuid Saúde [Internet]. 2017; [cited 2018 Apr 9]; 11(1):17-7. Available from: http://publicacoes.unigranrio.edu.br/index.php/rcs/article/ view/4506/2427

22. Carvalho VF, Silva FC, Oliveira KB, Silva MB, Buosi RB, Simões VAP. Tecnologias assistivas aplicadas a deficiência visual: recursos presentes no cotidiano escolar e na vida diária e prática. Educ Rev Educ [Internet] 2016 Jan/Jun; [cited 2018 Apr 11]; 16(1):61-74. Available from: http:// www.revistas.unipar.br/index.php/educere/article/view/5825/3318 
23. Pintanel AC, Gomes GC, Xavier DM, Cezar-Vaz MR, Silva MRS. Influência ambiental para a (in) dependência da criança cega: perspectiva da família. Aquichan [Internet]. 2016; [cited 2018 Apr 11]; 16(1):97-103. Available from: http://www.redalyc.org/ html/741/74144215010/

24. Silva CCB, Ramos LZ. Reações dos familiares frente à descoberta da deficiência dos filhos. Cad Ter Ocup UFSCar (São Carlos) [Internet]. 2014; [cited 2015 Jan 3]; 22(1):15-23. Available from: http://dx.doi. org/10.4322/cto.2014.003. DOI: http://doi.editoracubo.com.br/10.4322/ cto. 2014.003
25. Souza MP, Silva PAB, Freitas MLPF, Gatto MS. Habilidades sociais, interação social e a inclusão escolar de uma criança cega. Rev Educ Esp [Internet]. 2016 May/Aug; [cited 2017 Dec 11]; 29(55):323-36. Available from: https://periodicos.ufsm.br/educacaoespecial/article/ view/20002

a Article linked to the Master's dissertation: “Care for the child and teenager with visual impairment: family experience", approved in 2016, in the Master's Degree Course in Health Sciences, of the Postgraduate Program in Nursing, Federal University of São Carlos, by Mayara Caroline Barbieri, supervised by Giselle Dupas 